\title{
The Role of Pyrolysis and Gasification in a Carbon Negative Economy
}

\author{
Robert C. Brown
}

\section{check for}

updates

Citation: Brown, R.C. The Role of Pyrolysis and Gasification in a Carbon Negative Economy. Processes 2021, 9, 882. https://doi.org/ $10.3390 /$ pr9050882

Academic Editor: Albert Ratner

Received: 28 April 2021

Accepted: 11 May 2021

Published: 18 May 2021

Publisher's Note: MDPI stays neutral with regard to jurisdictional claims in published maps and institutional affiliations.

Copyright: (C) 2021 by the author. Licensee MDPI, Basel, Switzerland. This article is an open access article distributed under the terms and conditions of the Creative Commons Attribution (CC BY) license (https:// creativecommons.org/licenses/by/ $4.0 /)$.
Department of Mechanical Engineering, Iowa State University, Ames, IA 50011, USA; rcbrown3@iastate.edu

\begin{abstract}
The International Panel on Climate Change and the 2015 Climate Summit in Paris have recommended that efforts to reduce carbon emissions be coupled with carbon removal from the atmosphere. Carbon negative energy combines net carbon removal with the production of energy products or other revenue-generating products beyond sequestered carbon. Even though both biochemical and thermochemical approaches to carbon negative energy can be envisioned, this paper considers the prospects for the latter including pyrolysis and gasification. The fundamentals of these two processes are described to better understand how they would be integrated with carbon removal. Characteristics of pyrolysis and gasification are related to the kinds of sequestration agents they would produce, the scale of their deployment, the fraction of biomass carbon that could ultimately sequestered, the challenges of effectively sequestering these different forms of carbon and the economics of thermochemical carbon negative energy.
\end{abstract}

Keywords: carbon removal; carbon negative energy; pyrolysis; gasification; biomass; biochar

\section{Introduction}

Despite policymakers' efforts to regulate emissions of greenhouse gases, the concentration of carbon dioxide in in the atmosphere continues to rise. In 2014, the International Panel on Climate Change (IPCC) recommended that efforts to reduce carbon emissions be coupled with carbon removal from the atmosphere [1]. Similarly, the 2015 Climate Summit in Paris concluded that nations should strive for a balance between anthropogenic emissions by sources and removals by sinks of greenhouse gases [2].

Carbon emissions from the transportation, industrial and residential sectors can be substantially addressed through energy conservation and efficiency measures and switching to renewable energy. Carbon emissions from agriculture can be addressed through adoption of practices that reduce emissions of methane $\left(\mathrm{CH}_{4}\right)$, nitrous oxide $\left(\mathrm{N}_{2} \mathrm{O}\right)$ and carbon dioxide $\left(\mathrm{CO}_{2}\right)$ [3]. Technologies for carbon reduction are well established and commercially available but their implementation has been slowed by unfavorable economics compared to the status quo.

In contrast, carbon removal technologies are in their infancy and face even more daunting economic challenges than carbon reduction [4]. If carbon dioxide at a concentration of $410 \mathrm{ppm}$ is to be removed from the atmosphere (referred to as direct carbon removal or DCR), the energy requirement is substantial. To minimize the energy required to remove $\mathrm{CO}_{2}$ from air, Lackner proposed to "only skim the [air] stream for the highest available concentration of $\mathrm{CO}_{2}$ " [5].

Carbon removal can be generally categorized as biological or engineered approaches $[4,6]$. An appealing example of the former is shellfish aquaculture, which sequesters $0.22-0.44$ tons of $\mathrm{CO}_{2}$ as calcium carbonate in shells per ton of harvested shell fish [7]. Global mollusk harvest in 2014 was 16.1 million tons, thus sequestering 1-2 million tons of carbon annually. A prominent example of an engineering approach are the use of giant fans to move air past streams of aqueous sorbents to capture and concentrate $\mathrm{CO}_{2}$ for geological storage [8]

The shellfish example has two attractive features. First, it sequesters carbon as calcium carbonate, a solid that can be easily and safely stored for millions of years (as the White 
Cliffs of Dover in England testify). Second, seafood is a coproduct of the process, making it a potentially profitable enterprise even in the face of relatively modest prices for the sequestered carbon. In contrast, the only product from direct carbon capture powered by wind or solar energy is a concentrated stream of gaseous $\mathrm{CO}_{2}$, which is more difficult to securely and safely store than a solid carbonaceous product. Furthermore, the full burden of the enterprise's profitability is the price society is willing to pay for sequestered carbon. The cost of this DCR process is highly uncertain with estimates ranging from $\$ 200-\$ 600$ per metric ton carbon dioxide $\left(\$ / \mathrm{MT} \mathrm{CO}_{2}\right)[9-11]$ while markets for carbon abatement are well less than $\$ 100 / \mathrm{MT} \mathrm{CO}_{2}$.

The contrast between these two examples illustrates the attractiveness of carbon negative energy, a system that combines net carbon removal with the production of energy products or other revenue-generating products beyond sequestered carbon, as illustrated in Figure 1. The prospect of not only reducing but reversing the flow of carbon between the lithosphere and the atmosphere might appear to violate the Second Law of Thermodynamics. However, by powering the process with solar or other forms of renewable energy the process is perfectly feasible. If widely adopted by society, carbon negative energy would result in a carbon negative economy in which economic activity removed rather than added $\mathrm{CO}_{2}$ to the atmosphere. It should be noted that natural ecosystems are frequently carbon negative energy systems such as marshlands building soil carbon and coral reefs building limestone formations.

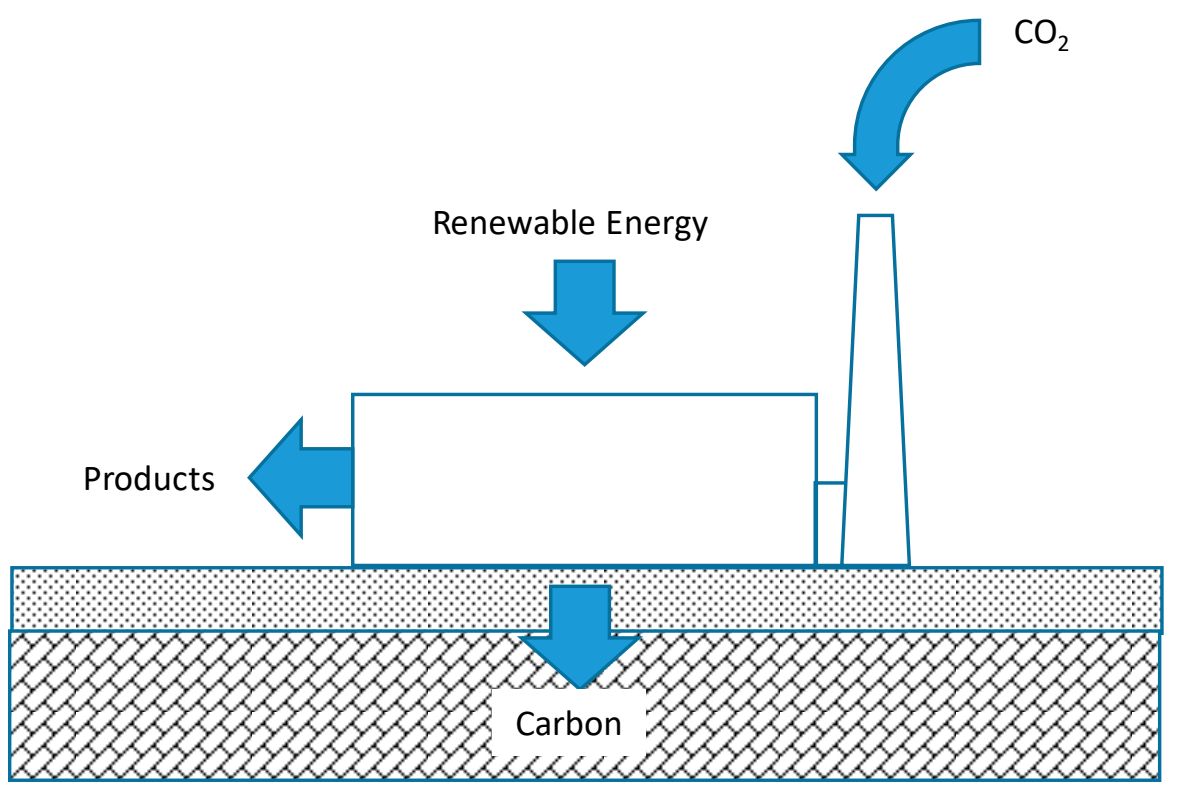

Figure 1. Carbon negative energy reverses the flow of carbon between lithosphere and atmosphere in production of energy for society, powered by renewable energy.

Notably, natural ecosystems store carbon as relatively stable solids with the prominent exceptions of methane clathrates and carbon dioxide hydrates, which are stable only at the low temperatures and high pressures found in deep ocean trenches or artic environments [12]. Ideally, human-constructed carbon negative energy systems would sequester carbon as recalcitrant solids. However, many proposed systems would sequester carbon as gaseous $\mathrm{CO}_{2}$ in depleted gas and oil wells, saline aquifers or deep ocean water, as subsequently discussed.

Both biochemical and thermochemical processes could be combined with carbon removal to achieve carbon negative energy. A prominent example of the former is the geological sequestration of the almost pure co-product stream of $\mathrm{CO}_{2}$ from grain ethanol plants [13]. However, the focus of this paper is thermochemical carbon negative energy systems based on either pyrolysis or gasification of biomass. The fundamentals of these processes are briefly outlined, their strengths and weaknesses in converting biomass into 
energy and chemical products described and the prospects for integrating them with carbon removal reviewed.

\section{Thermochemical Processes for Carbon Negative Energy}

In principle, purely thermochemical processes can be envisioned that employ solar or wind power to remove carbon dioxide from the atmosphere and transform it into both carbon sequestration agent and marketable products. In practice, most thermochemical processes are energetically driven by the chemical energy of their feedstocks. Thus, thermochemical processes for carbon negative energy typically exploit natural photosynthesis in plants to fix carbon from the atmosphere as energy-rich chemical bonds in biomass. This biomass can then be thermochemically processed into power, fuels, commodity chemicals or materials. Part or even all of the carbon in the feedstock is extracted and stored in the biosphere as char (commonly referred to as biochar to emphasize its value in providing ecosystem services) or in deep oceans or geological formations as gaseous or dissolved $\mathrm{CO}_{2}$ (see Figure 2). In this way, thermochemical processing is able to couple bioenergy production with carbon removal to achieve carbon negative energy.

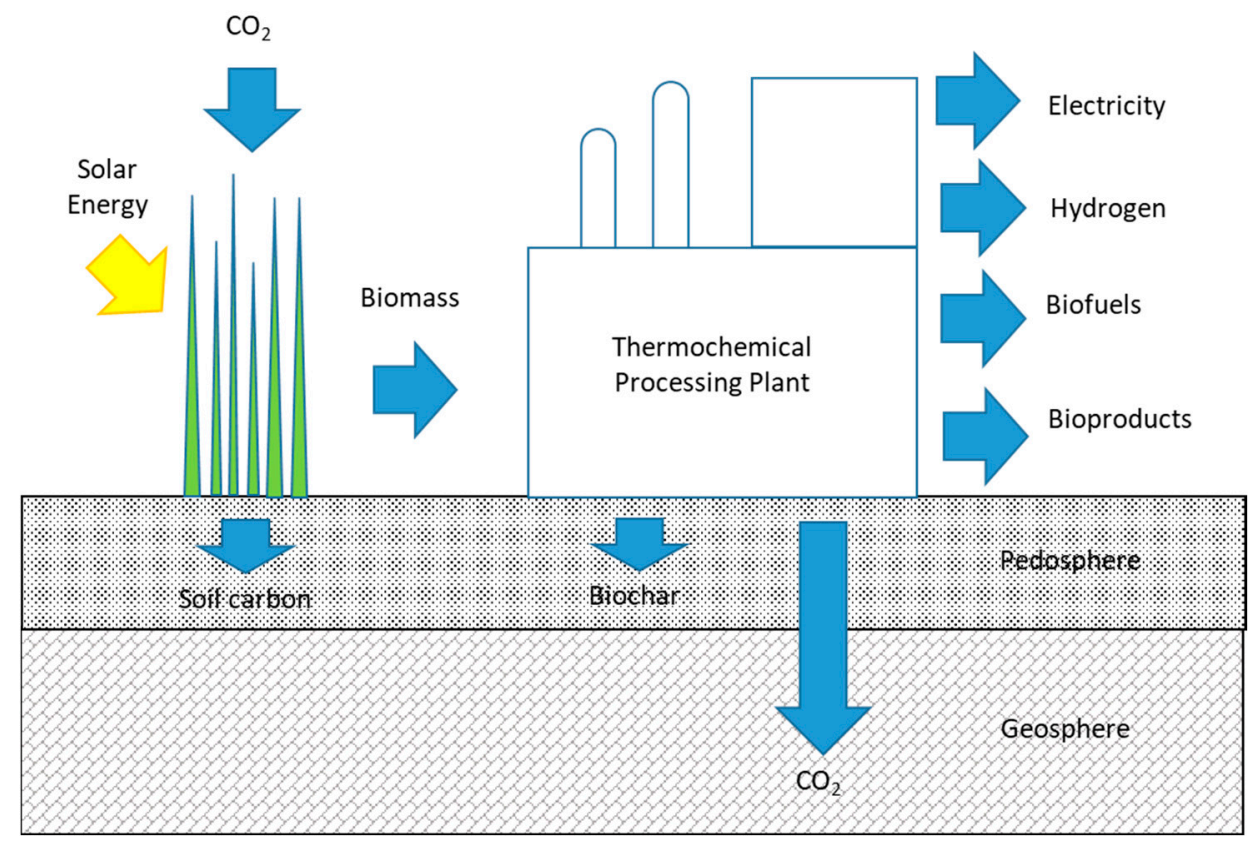

Figure 2. Carbon negative energy through integration of thermochemical processing of biomass and carbon removal technologies.

Of course, the availability of biomass is just as much a question for carbon negative energy as it is for biofuels. The U.S. Department of Energy (DOE) released a comprehensive report on this subject in 2005 that estimated 1.4 billion tons of biomass would be annually available in the U.S. by 2030 from a combination of forest and agricultural biomass and wastes and dedicated energy crops [14]. A 2011 update on this report concluded that up to 1.6 billion tons of biomass were potentially available despite reducing the contribution of agricultural residues to mitigate soil erosion from excessive removal of residues [15]. This was followed by a similarly comprehensive report by the U.S. DOE in 2016 that estimated 1.2-1.5 billion tons would be available at less than $\$ 60 /$ ton by 2040 [16]. Assuming $47 \%$ of this mass is carbon, then thermochemical processing of biomass could remove 200-2750 million tons of $\mathrm{CO}_{2}$ from the atmosphere annually, depending on the extent that feedstock supply develops and the thermochemical technology employed.

The three major thermochemical technologies considered in this review are slow pyrolysis, fast pyrolysis and gasification. Solvent liquefaction in both organic liquids and water (the latter referred to as hydrothermal processing) is a unique category of 
thermochemical processing [17] that is beyond the scope of this review although it also has potential for carbon negative energy.

Figure 3 illustrates the fundamental processes responsible for slow pyrolysis, fast pyrolysis and gasification [18]. All three processes begin by heating a particle of biomass or other solid organic material. A thermal front penetrates the particle, raising its temperature high enough to first drive off moisture after which the temperature continues to rise to the reactor temperature $\left(300-600{ }^{\circ} \mathrm{C}\right.$ for pyrolysis and $800-1500{ }^{\circ} \mathrm{C}$ for gasification). Light gases and vapors, including carbon monoxide $\mathrm{CO}, \mathrm{CO}_{2}$, produced water, hydrogen $\left(\mathrm{H}_{2}\right)$, light hydrocarbons and heavy organic compounds (known as tar) are released from the solid at temperatures as low as $250{ }^{\circ} \mathrm{C}$ and continuing up to $500{ }^{\circ} \mathrm{C}$. Most commonly this process is endothermic although it can be exothermic under certain conditions as subsequently described.

Heating and Drying

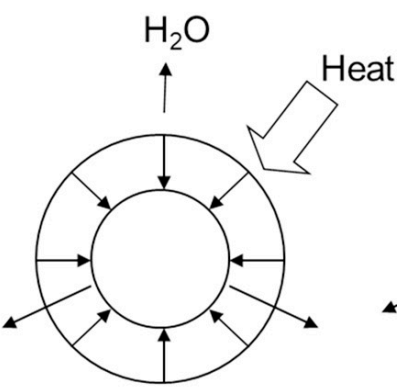

Thermal front penetrates particle
Devolatilization

Volatile gases:

$\mathrm{CO}, \mathrm{CO}_{2}, \mathrm{H}_{2}, \mathrm{H}_{2} \mathrm{O}$, Light hydrocarbons, and tar

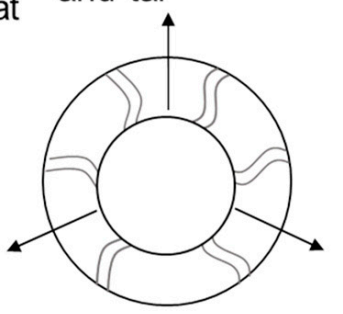

Porosity increases
Gas-Solid Reactions

\section{Gas-phase Reactions}

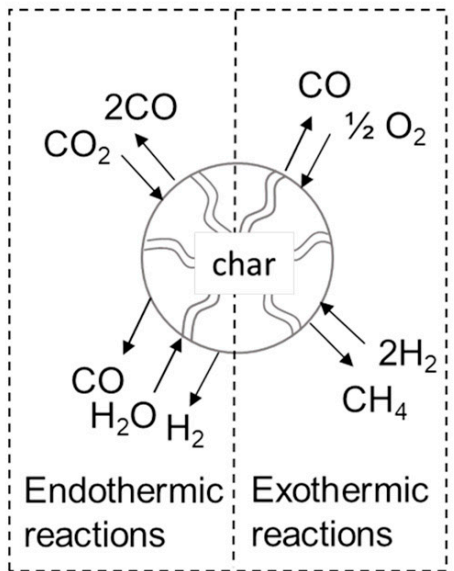

$$
\begin{aligned}
& \mathrm{CO}+\mathrm{H}_{2} \mathrm{O} \leftrightarrow \mathrm{CO}_{2}+\mathrm{H}_{2} \\
& \mathrm{CO}+3 \mathrm{H}_{2} \leftrightarrow \mathrm{CH}_{4}+\mathrm{H}_{2} \mathrm{O} \\
& \mathrm{CH}_{4}+\mathrm{H}_{2} \mathrm{O} \leftrightarrow \mathrm{CO}+3 \mathrm{H}_{2}
\end{aligned}
$$

Tar cracking

Figure 3. Fundamental steps in slow pyrolysis, fast pyrolysis and gasification. Note that devolatilization is generally endothermic while the gas-phase reactions as written are exothermic. (Adapted with permission from ref. [18]. Copyright 2014 Wiley Books.)

The combination of heating, drying and devolatilization at modest temperatures $\left(<600{ }^{\circ} \mathrm{C}\right)$ in the absence of oxygen is characterized as pyrolysis. Slow pyrolysis occurs when the heating of the particle is relatively slow and residence times of released vapors is relatively long, both of which encourage formation of char vs. liquid product and likely approaches chemical equilibrium in the distribution of products. Fast pyrolysis is a nonequilibrium process that strives for rapid particle heating and short vapor residence times for the purpose of maximizing liquid products at the expense of char. As temperature increases, chemical equilibrium favors the conversion of both char and condensable vapors (tar) into $\mathrm{CO}$ and $\mathrm{H}_{2}$ [19]. This increasing prevalence of permanent gases among products with increasing temperature, the result of the gas-solid and gas-phase reactions illustrated in Figure 3, represents a transition to gasification.

Even though neither pyrolysis nor gasification requires oxygen to proceed, both require a source of energy to drive the predominately endothermic reactions of these processes [20]. Occasionally for gasification and traditionally for pyrolysis, this energy is provided through direct or indirect heat exchange between the reactor and a furnace, the latter often fired with char produced from the pyrolyzer or gasifier. Most gasifiers, though, admit oxygen $\left(\mathrm{O}_{2}\right)$ or air to the reactor at equivalence ratios (defined as the actual oxygen/fuel ratio divided by the stoichiometric oxygen/fuel ratio) of around $0.20-0.25$ to partially oxidize products of gasification and thus provide the energy demand for the process, achieving what is known as "autothermal operation" [19]. In this scheme the gas product is diluted with the products of this oxidation $\left(\mathrm{CO}_{2}\right.$ and additionally nitrogen gas in 
the case of air-blown gasification). The resulting simplifications in reactor design and operation often justifies this autothermal approach to gasification. Recent research has shown that fast pyrolyzers also can be operated autothermally by admitting air at equivalence ratios of $0.06-0.12$, accompanied by dramatic intensification of pyrolysis while suffering only minor losses in oil yield [21].

If $\mathrm{O}_{2}$ is present in the reactor, it is generally not able to diffuse to the surface of the particle until devolatilization is complete, which may be a few seconds for fast pyrolysis or several minutes or even longer for slow pyrolysis [18]. Under conditions of high temperature and oxygen equivalence ratios, volatiles rapidly oxidize in a spherical shell immediately surrounding the particle, which is characterized as flaming combustion. At lower temperatures and equivalence ratios, as occurs in autothermal pyrolyzers and gasifiers, the volatiles burn more diffusely in the gaseous volume of the reactor. Once the particle has devolatilized to a porous carbonaceous solid (char), $\mathrm{O}_{2}$ can diffuse to its surface or even into the particle's pores and react to form $\mathrm{CO}$. Other gas-solid reactions upon completion of devolatilization include reaction of biochar with $\mathrm{CO}, \mathrm{H}_{2}$ and water to form $\mathrm{CO}_{2}$, methane $\left(\mathrm{CH}_{4}\right)$ and $\mathrm{CO}$ and $\mathrm{H}_{2}$, respectively.

Some of the major characteristics that distinguish slow pyrolysis, fast pyrolysis and gasification are summarized in Table 1 . These are described in more detail in the sections that follow.

Table 1. Characteristics of thermochemical processes for use in carbon negative energy.

\begin{tabular}{cccc}
\hline & Slow Pyrolysis & Fast Pyrolysis & Gasification \\
\hline Thermodynamics & Equilibrium & Non-equilibrium & Equilibrium \\
Feedstock grind & Coarse & Fine & Large range \\
Heating rate & Slow & Fast & Moderate-Fast \\
Temperature & $300-600{ }^{\circ} \mathrm{C}$ & $400-600{ }^{\circ} \mathrm{C}$ & $800-1500{ }^{\circ} \mathrm{C}$ \\
Pressure* & Elevated & Atmospheric & Elevated \\
Gas residence time * & Long & Short & Long \\
Major product & Solid & Liquid & Gas \\
Scale & Small & Moderate & Large \\
Biochar yield & $25-45 \mathrm{wt} \%$ & $10-20 \mathrm{wt} \%$ & $0-10 \mathrm{wt} \%$ \\
Biomass carbon & $<55 \%$ & $<20 \%$ & $50-100 \%$ \\
sequestered & Low & High & Low \\
Other sequestration & Low & Moderate & High \\
products & Marginal & Moderate & Low \\
Capital cost & & & \\
Profitability & & &
\end{tabular}

\section{Pyrolysis as a Pathway to Carbon Negative Energy}

Pyrolysis is traditionally defined as the thermal deconstruction of solid organic materials in the absence of oxygen [22] although it may also occur in the presence of oxygen under conditions of low equivalence ratios [21]. Slow pyrolysis, operating at temperatures comparable to fast pyrolysis, is distinguished by much lower heating rates [23] resulting in char and gas rather than liquid being the primary products. As illustrated in Figure 4, char yields increase with decreasing temperature and heating rate [24]. Theoretical yields of char, based on proximate analysis, can be $50-70 \mathrm{wt} \%$ although actual yields are usually less than $80 \%$ of theoretical values [25]. A number of other operating conditions can influence char yields, including grind of feedstock, reactor ventilating rate and operating pressure. Large particles tend to produce higher char yields especially at lower pyrolysis temperatures (see Figure 5) [26]. Increasing the pressure of operation and decreasing the ventilation rate of gas through a pyrolysis reactor encourages volatiles to condense and dehydrate to form so-called secondary char to distinguish it from char formed directly from solid organic material. As shown in Figure 6a, char yields can increase 30\% in moving from high to low 
ventilation rates and can increase by over $80 \%$ in increasing pressure from atmospheric to $2.5 \mathrm{MPa}$. The literature contains contradictory reports on the effect of moisture on char yields, [27] although Antal et al. [28] provide evidence that moisture improves yields in closed, pressurized kiln vessels.

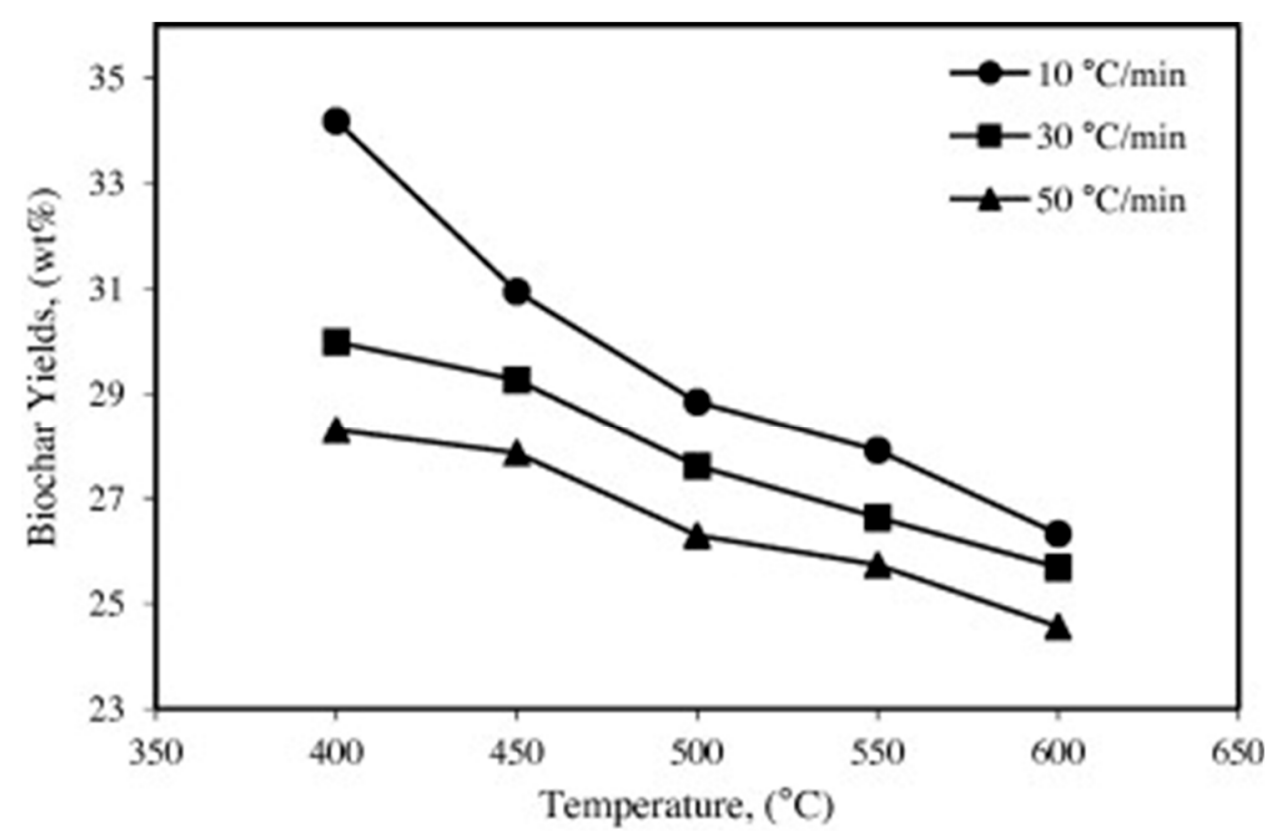

Figure 4. Effect of temperature and heating rate on char yields from safflower seed cake. (Reprinted with permission from ref. [24]. Copyright 2013 Elsevier.)

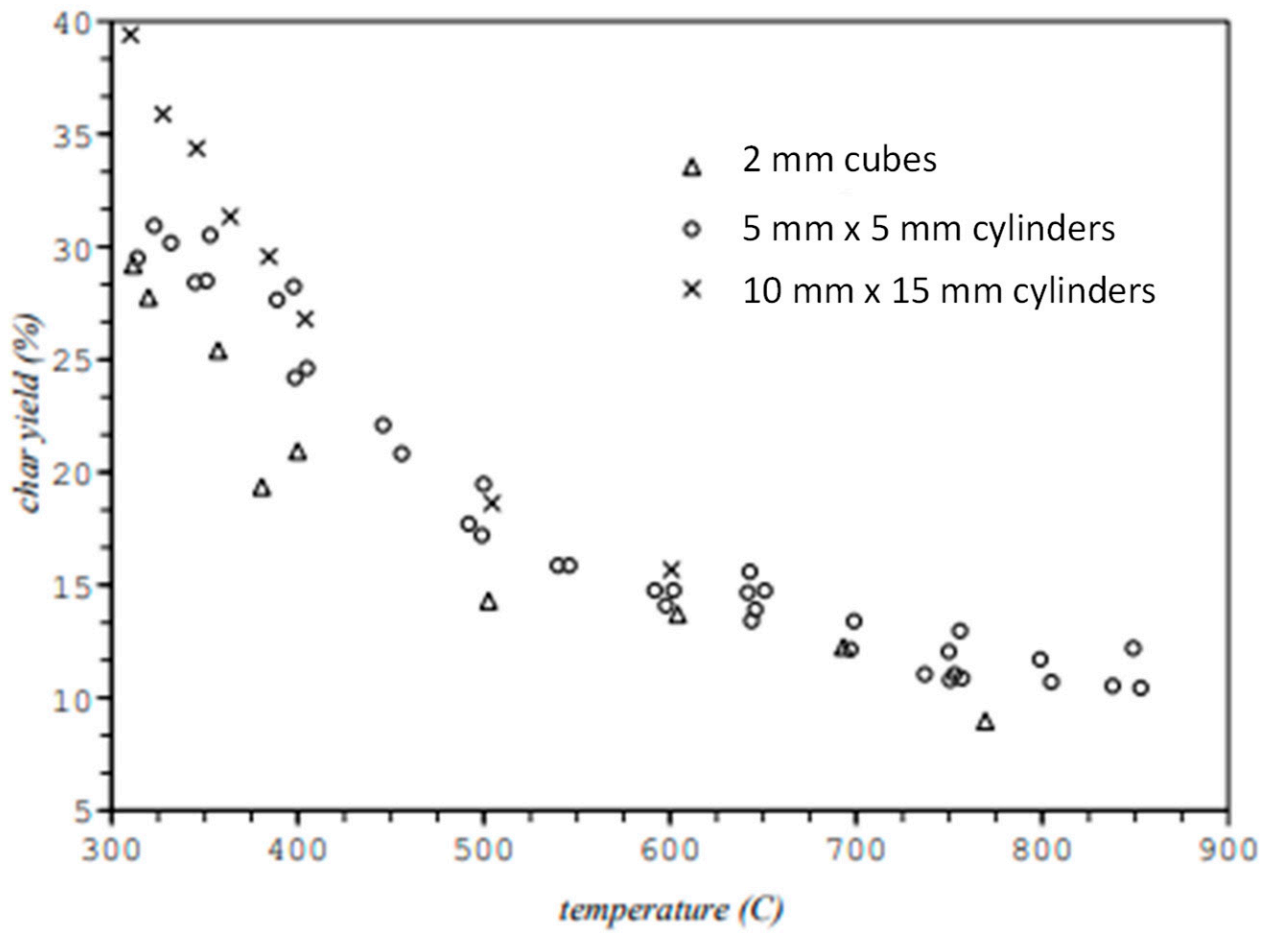

Figure 5. Effect of particle size and temperature on char yield during pyrolysis of thermally thick particles. (Reprinted from ref. [26].) 

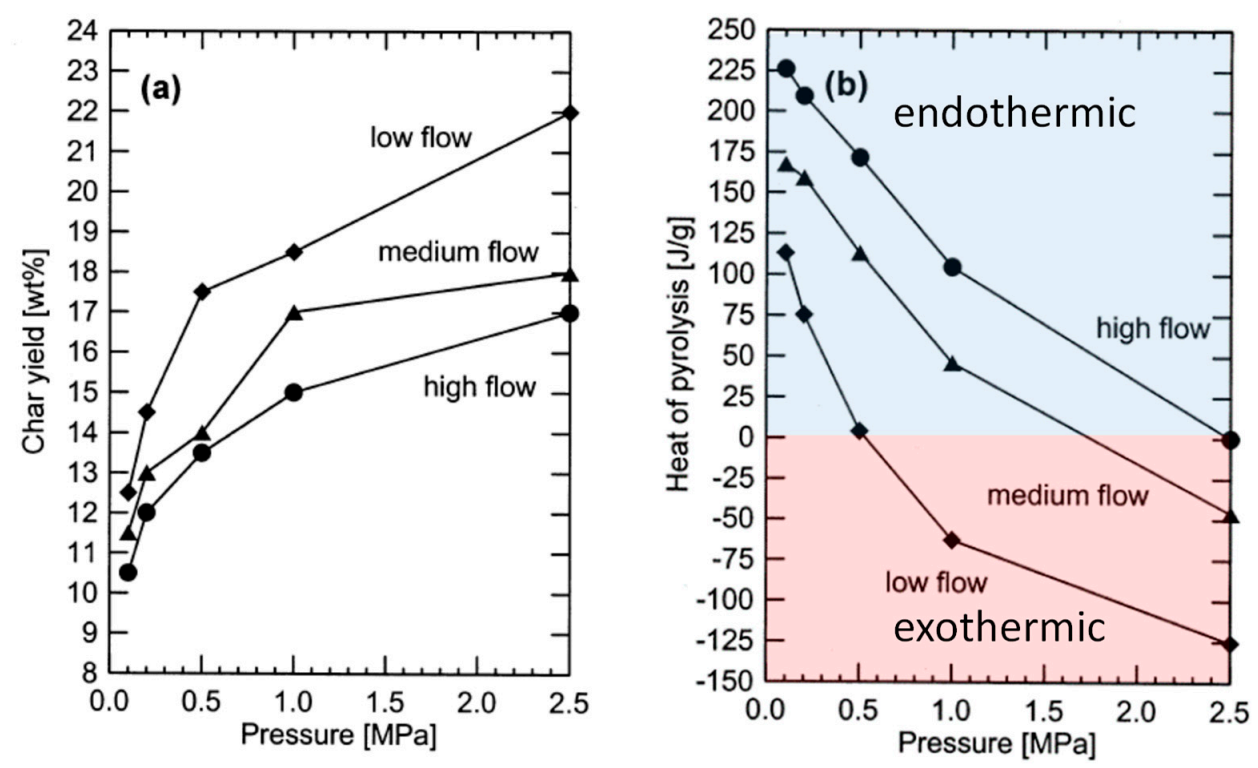

Figure 6. Char yield (a) and enthalpy for pyrolysis (b) as functions of operating pressure and ventilation rate during slow pyrolysis of biomass. (Adapted with permission from ref. [29]. Copyright 2014 Thermochimica Acta).

A prominent advantage of slow pyrolysis for carbon negative energy is the simple construction and operation of slow pyrolysis reactors, making them suitable for small plants processing widely distributed biomass supplies. As illustrated in Figure 6b, if operated at elevated pressure (above $0.5 \mathrm{MPa}$ ) and low ventilation rates, slow pyrolysis has prospects for being an exothermic process, requiring neither an external source of heat nor partial oxidation of products to drive the process [29]. Even though pressurized "charcoal kilns" have been demonstrated, [28] they bring additional cost of construction and complexity of operation that negates an important advantage of slow pyrolysis.

Fast pyrolysis is characterized by rapid heating of solid organic material followed by rapid cooling of the volatilized products to assure maximum yield of condensable organic vapors from this non-equilibrium process. If vapors released from devolatilizing biomass dwell too long at pyrolysis temperatures, they undergo secondary reactions that crack heavy molecules to light oxygenated compounds (especially in the presence of hot char particles) [30] or repolymerize phenolic compounds to high molecular weight oligomers, [31,32] neither of which are particularly desirable liquid products for upgrading to fuels or chemicals. Under conditions of rapid heating, most volatiles are released in as little as 1-2 s, [33] although devolatilization can continue for as long as $40 \mathrm{~s}$ [34]. Accordingly, solids residence times should be much longer than vapor residence times to minimize volatile content of char and maximize bio-oil yields from condensation of volatiles downstream of the pyrolysis reactor. The optimal temperature for maximum bio-oil yields occurs around $500{ }^{\circ} \mathrm{C}$ (see Figure 7) [35]. At higher temperatures both bio-oil and char yields decrease; that is the process shifts towards gasification of the solid organic reactant.

To favor liquid over char formation, both high heat fluxes at the surface of the biomass particles and rapid conduction of heat to the center of the particle are critical. Over the years, a wide range of reactor configurations have been evaluated to rapidly convey heat to the surface of particles while rapidly transporting vapors out of the reactor without overheating the particles [22]. Due to their outstanding convection coefficients, fluidized beds have been widely employed for fast pyrolysis, either bubbling or circulating beds. In continuous operation, char particles, which tend to accumulate at the surface of the bed, can be removed with an overflow pipe. However, their low particle density and high friability compared to the starting biomass causes attrited char to readily elutriate from the bed with gases and vapors where they can be separated from the product stream with gas cyclones. 


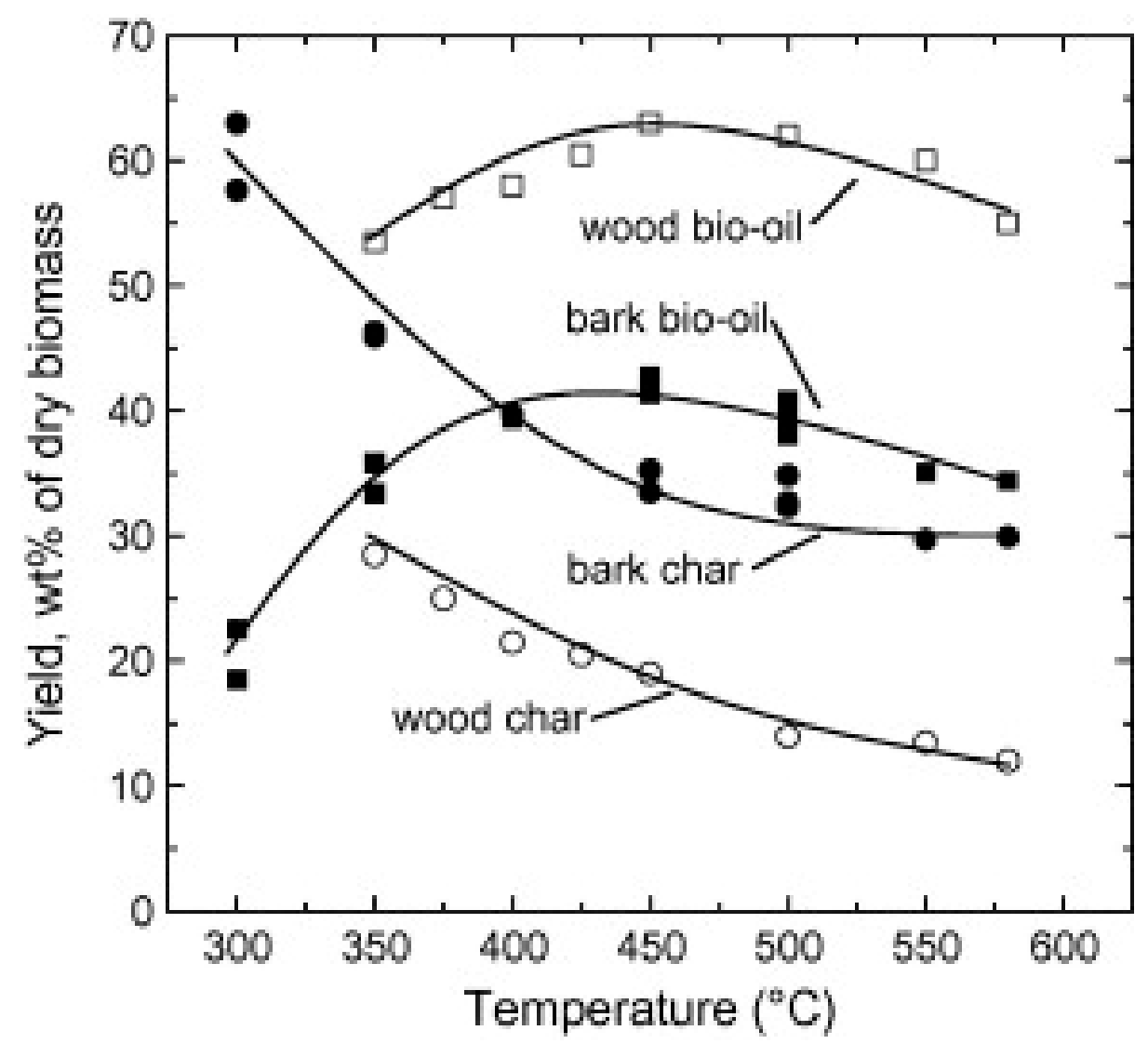

Figure 7. The optimal temperature for maximum bio-oil yield occurs at $450-500{ }^{\circ} \mathrm{C}$ (Reprinted with permission from ref. [35]. Copyright 2013 Fuel).

Pyrolysis reactors can be categorized according to the method that the energy for pyrolysis is provided to them: indirectly heated, directly heated and autothermal operation [36]. Indirectly heated reactors either pass hot gases around the reactor perimeter or through heat exchange tubes within the reactor (for research reactors electrical heaters are sometimes used to provide this thermal energy). Achieving high heat fluxes at modest temperatures can be problematic in gaseous environments. Even though fluidized beds can achieve high heat fluxes at reactor walls or heat exchange surfaces, erosion can be a problem and immersed tubes can compromise the mixing of sand and gas that is responsible for the high convection coefficients of fluidized beds. Directly heated reactors contact heat transfer media with the biomass to improve heat transfer rates compared to indirect heat transfer. Even though the sensible enthalpy of gases may be adequate for the modest endothermicity for slow pyrolysis $(<0.225 \mathrm{MJ} / \mathrm{kg}$, see Figure $6 \mathrm{~b})$, it is inadequate for providing the enthalpy for fast pyrolysis, which is on the order of $1 \mathrm{MJ} / \mathrm{kg}$ [37]. For this reason, granular media is often employed to transport thermal energy from a heat source to the reactor, usually either a fluidized bed [38] or an auger reactor [39].

Autothermal operation provides the enthalpy for pyrolysis through partial combustion of either the reactant or products of pyrolysis [40]. Traditional charcoal kilns operate on this principle, with a fire ignited in a pile of wood covered with earth except for a few vents at the bottom and a small flue at the top for the purpose of providing just enough air to meet the energy needs for slow pyrolysis of the wood [41]. The possibility of autothermal operation of fast pyrolyzers received little attention until recently, probably because it seemed likely that oxygen would preferentially oxidize the vapors intended for bio-oil production. In fact, in a fluidized bed reactor, the oxygen preferentially oxidizes char with only a small penalty on bio-oil yield [42,43]. Not only does autothermal pyrolysis simplify reactor design and operation, it achieves several-fold process intensification in reactor 
throughput by overcoming the heat transfer bottleneck of conventional (non-oxidative) pyrolysis [40].

Both slow and fast pyrolysis produce solid carbon sequestration products although slow pyrolysis produces as much as three times more char. Despite these advantages, an economic study by Brown et al. [44] suggests that it would be a less profitable enterprise for the production of char than fast pyrolysis. The only co-product of slow pyrolysis is a low caloric value gas that today is only worth $\$ 2-4 / G J$ while fast pyrolysis produces bio-oil and gas as co-products. The bio-oil can be upgraded to transportation fuel worth $\$ 23 / \mathrm{GJ}$ or more.

Char has several advantages as a carbon sequestration agent. Marmiroli et al. [45] estimate the bulk density of wood char to be around $450 \mathrm{~kg} / \mathrm{m}^{3}$ while Brewer et al. [46] report carbon content of $80 \%$, thus achieving $364 \mathrm{~kg}$ carbon storage per cubic centimeter. This is several fold greater than for $\mathrm{CO}_{2}$ even when stored under tens of atmospheres of pressure [47]. Char is also recalcitrant, with a half-life measured in hundreds of years or even longer even when stored in soils [48]. Finally, char stored in soils, in which case it is referred to as biochar, provides ecosystem services beyond carbon sequestration including improving the water holding and nutrient retention capacities of soil [49-51]. The annual carbon removal potential of biochar has been estimated to be as much as 1.2 trillion tons of carbon, representing $10 \%-15 \%$ of the total carbon removal potential of terrestrial ecosystems [52].

One of the major challenges of biochar as carbon sequestration agent is lack of uniform properties among biochars, which are dependent on the feedstock and pyrolysis conditions. For example, the high ash content of herbaceous biomass results in biochars with lower fixed carbon content than woody biomass [46], reducing its carbon sequestration potential per unit mass. Biochar produced at lower temperatures and shorter solids residence times contain more volatile matter (labile carbon) [53], which very quickly mineralizes in soils and does not contribute toward long-term carbon sequestration [54]. Biochar production often yields a fine powder (see Figure 8), which can be difficult to apply on fields and can even be a fire hazard. However, this problem can be largely mitigated through prilling the biochar with a small amount of binder material into granules, as shown in Figure 8.

\section{Fine biochar from pyrolyzer}
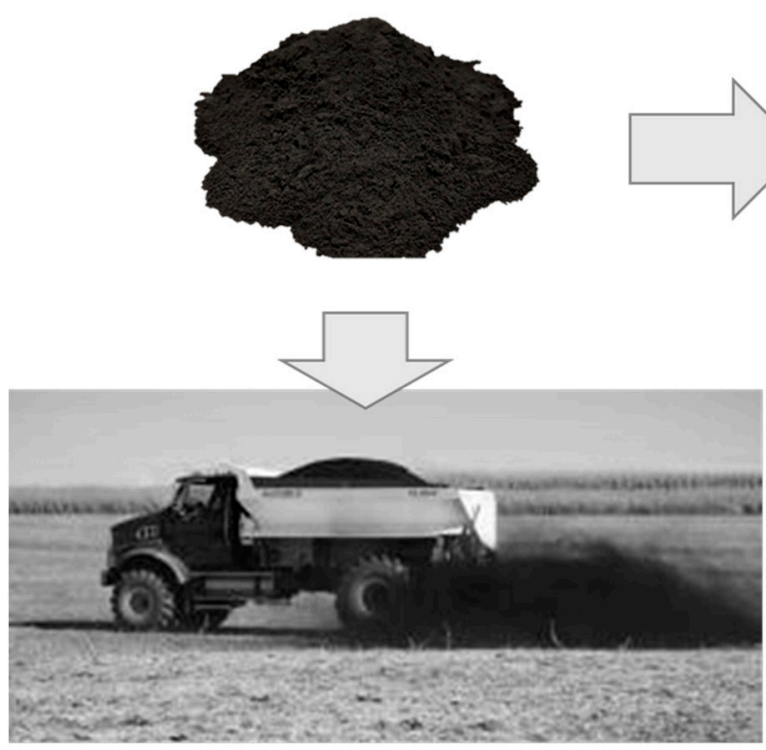

Dust from application of fine biochar

\section{Disk prilling machine}

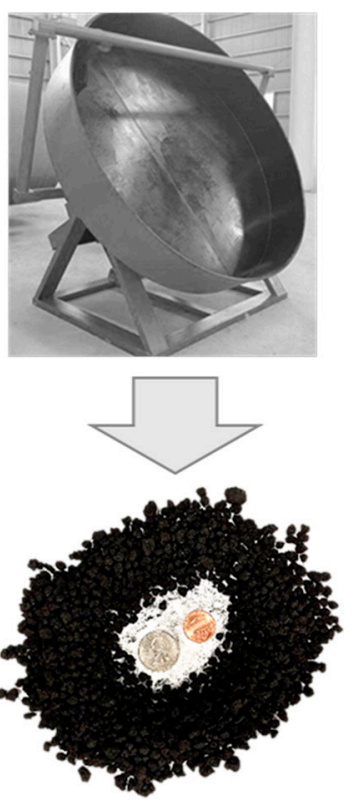

Granulated biochar

Figure 8. Fine biochar from many kinds of pyrolyzers is problematic in field application, which can be mitigated through prilling to granular biochar. 
Fast pyrolysis technology has undergone significant advancement since its emergence in the early $1980^{\prime}$ s. Readers seeking more comprehensive information on these advances are directed to a recent review article [21] and book [55] on the subject prepared by the author.

\section{Gasification as a Pathway to Carbon Negative Energy}

Gasification can be broadly characterized according to the method by which thermal energy is provided to support devolatilization of biomass and other endothermic reactions including gas-solid reactions and gas-phase reactions (see Figure 3) [19]. These include indirect heating (allothermal gasification) using an external heat source and partial oxidation (autothermal gasification) in which combustion at equivalence ratios of $0.2-0.3$ releases enough thermal energy to support the endothermic reactions of the process.

Most allothermal gasifiers are based on fluidized bed reactors with heat supplied by transporting hot granular bed media between a combustor and the gasification vessel [19]. However, there are also chemical looping allothermal gasifiers that transfer chemical energy between a combustor and gasifier [56]. These system have the advantage of producing high caloric-value gas with relatively little carbon dioxide (from combustion) or nitrogen (from air) that characterize partial oxidation gasification. However, they add an additional level of complexity in the design and operation of the gasifier.

Autothermal gasifiers can be either air-blown or oxygen-blown [19]. Air-blown gasifiers are relatively simple but generally operate at lower temperatures than oxygen-blown systems and the product gas is heavily diluted with nitrogen from the air. Oxygen-blown gasifiers, by operating at higher temperatures, attain very high carbon conversion and produce gas that is mostly $\mathrm{CO}$ and $\mathrm{H}_{2}$. Of course, the need for oxygen increases the capital and operating costs for these more efficient gasifiers.

The intended use of the product gas strongly influences whether the gasifier is designed to operate at elevated pressures, which can be 10 bar or higher. Atmospheric gasification is suitable for many process heat applications and gas fermentation [57]. However, for use in gas turbine or gas-to-liquids synthesis, pressurized gas is required. Even though gas from an atmospheric pressure gasifier could be cooled and compressed to pressures appropriate for downstream applications, it is rarely deemed practical because of the large volume of gas generated in the gasifier. Generating the gas in a pressurized reactor is more energy efficient although the need for pressure vessels and feedstock lock hoppers adds to the complexity and capital cost of the installation.

Biomass gasifiers can be further classified according to the methods used to contact solid feedstock and gasification agents (steam, oxygen and/or air). These include updraft, downdraft, fluidized beds and entrained flow (see Figure 9) [18]. Updraft and downdraft gasifiers are both fixed bed reactors with biomass moving downward through them by gravity. Updraft gasifiers were the basis of the earliest gasifiers. Biomass is fed from the top of the gasifier onto a grate through which air flows upward. Even though very simple in operation, the counterflow of biomass and air produces high concentrations of tar. It is generally not considered suitable for modern heat and power systems. The downdraft gasifier is a distinct improvement over updraft gasifiers. An induced draft fan draws gases downward through a grate, causing the concurrent downward flow of biomass and gases (air and product gas). Air is drawn into the gasifier at a constriction in the cross-section of the reactor known as the throat where charcoal is oxidized to high temperatures. Biomass approaching the hot charcoal is pyrolyzed to vapors and additional charcoal. The vapors flow through the hot charcoal where tars are cracked to light gases while the fresh charcoal replenishes the burned charcoal. This gasifier produces gas with very little tar, but is not readily scaled beyond $400 \mathrm{~kg} / \mathrm{h}$. 


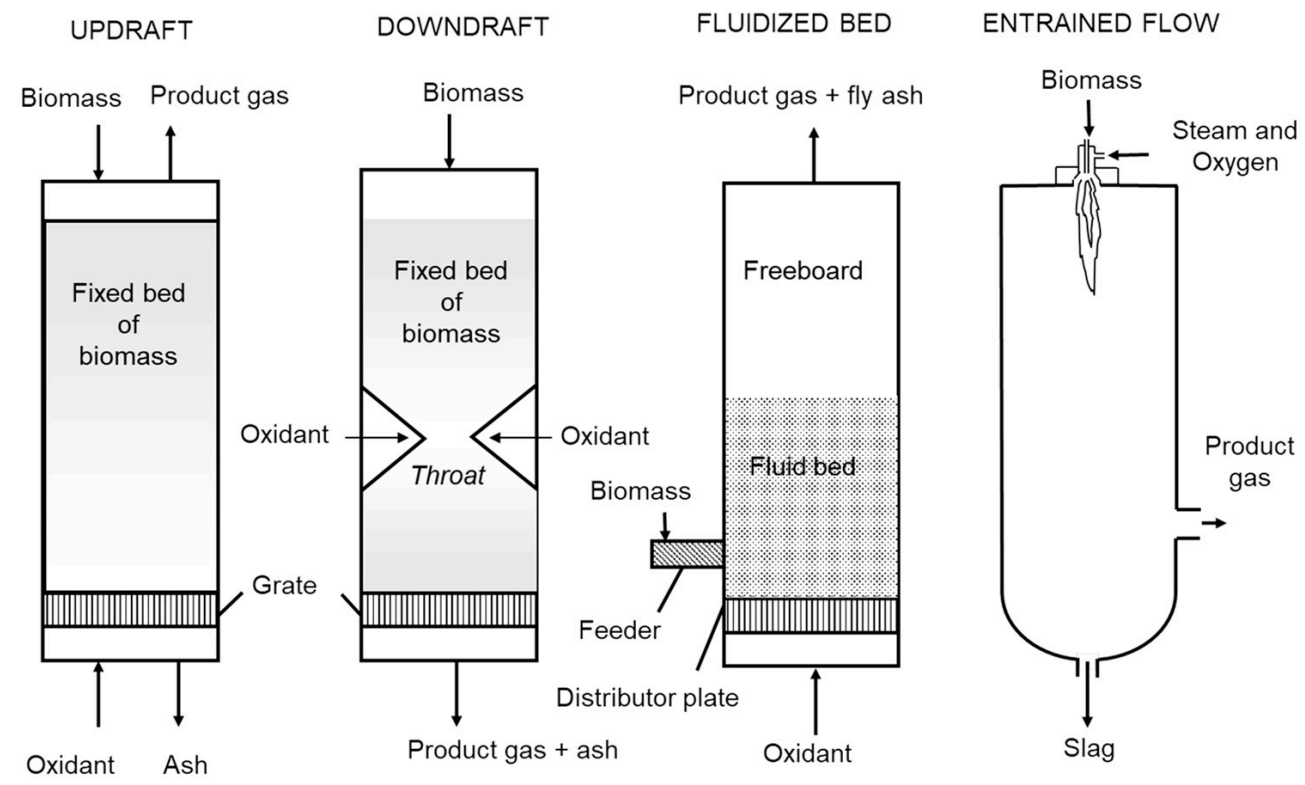

Figure 9. Classification of gasifiers according to the method of contacting solid feedstock and gasification agent (Reprinted with permission from ref. [18]. Copyright 2014 Wiley Books.)

The fluidized bed gasifier is a multi-phase system of gas and particulate matter [39]. A bubbling fluidized bed consists of an emulsion phase of particulate matter suspended in an upward flowing gas and a bubble phase consisting of large voids moving upward through the emulsion phase. A bubbling fluidized bed transitions to a circulating fluidized bed when sufficient gas is passed through the reactor to cause a dilute suspension of particulate matter with no discernible bubble phase. Particulate matter is continuously circulated between the reactor (riser) and the return line (standpipe). Both kinds of fluidized beds are characterized by high rates of heat transfer and solids mixing. The bubbling fluidized bed is of simpler design and is probably more suited for smaller scale applications. The circulating fluidized bed achieves higher carbon conversion because of the circulation of solids between riser and standpipe. It is more appropriate for larger scale applications.

Entrained flow gasifiers achieve very high carbon conversions and virtually tar-free product gas by reacting very fine particles of solid fuel in a stream of pure oxygen at temperatures of $1200-1500{ }^{\circ} \mathrm{C}$ [19]. At these temperatures, ash in the feedstock melts and forms a slag that flows down the walls of the gasifier to a quench section. Due to their high gasification efficiency, entrained flow reactors have been favored in commercial-scale gasification of coal [58]. However, entrained flow reactors face several limitations in biomass gasification. The requirement of feedstock being comminuted to sizes finer than $200 \mu \mathrm{m}$ [59] is a significant barrier to utilizing them for biomass gasification. While coals are friable materials that are easily crushed to fine particles, biomass fibers are inherently elastic and are more apt to bend than break under compressive forces. Thus, significant energy is consumed in comminuting biomass compared to coal and minerals [60]. For pressurized gasification, coal particles are frequently mixed with water to form pumpable slurries containing as much as $50 \%$ coal that can be injected at high pressures into the gasifier. The hydrophilic nature of biomass makes it impossible to produced high solids content slurries. Grindability and hydrophobicity of biomass can be remarkably increased through torrefaction of biomass, although this adds significantly to production cost of producer gas [61]. The slagging of ash in high temperature entrained flow gasifiers is a distinct disadvantage in the gasification of biomass since the ash includes the important plant nutrients of potassium and phosphorous. Experiments in gasification of biomass in entrained flow reactors have found that these nutrients react to form melts of potassium silicates or crystals of phosphates and diphosphates, [62] which would ultimately report to the slag in vitrified form, likely making these nutrients no longer plant available. Considering the looming worldwide shortage of 
phosphorous, [63] this is an important issue to resolve before adopting this technology for carbon negative energy.

The gaseous product of biomass gasification is ideally a mixture of non-condensable gases consisting primarily of $\mathrm{CO}$ and $\mathrm{H}_{2}$ and smaller amounts of $\mathrm{CO}_{2}$ and light alkanes and alkenes [64]. In practice it can contain significant tar, hydrogen sulfide $\left(\mathrm{H}_{2} \mathrm{~S}\right)$, carbonyl sulfide $(\mathrm{COS})$, ammonia $\left(\mathrm{NH}_{3}\right)$, hydrogen cyanide $(\mathrm{HCN})$, hydrogen chloride $(\mathrm{HCl})$ and alkali metals. Most of these represent serious air pollutants if the gas is combusted or catalyst poisons if the gas is used in chemical synthesis. Thus, they must be removed often to very low concentrations depending on the downstream application (see Table 2) [18]. In many cases, separate unit operations are required for each contaminant to achieve the very high levels of removal required for some applications, which adds considerably to the expense of gasification [65].

Table 2. Contaminant removal levels for various applications of producer gas. (Reprinted with permission from ref. [18]. Copyright 2014 Wiley Books.)

\begin{tabular}{ccccc}
\hline & \multicolumn{3}{c}{ Application } \\
\hline Contaminant & IC Engine & Gas Turbine & Methanol Synthesis & FT Synthesis \\
\hline Particulate & $<50 \mathrm{mg} / \mathrm{m}^{3}$ & $<30 \mathrm{mg} / \mathrm{m}^{3}$ & $<0.02 \mathrm{mg} / \mathrm{m}^{3}$ & not detectable \\
Tars & $<100 \mathrm{mg} / \mathrm{m}^{3}$ & $<8 \mathrm{mg} / \mathrm{m}^{3}$ & $<0.1 \mathrm{mg} / \mathrm{m}^{3}$ & $<10 \mathrm{ppb}$ \\
Sulfur & - & $<20 \mathrm{ppm}$ & $<1 \mathrm{mg} / \mathrm{m}^{3}$ & $<10 \mathrm{ppb}$ \\
Nitrogen & - & $<50 \mathrm{ppm}$ & $<0.1 \mathrm{mg} / \mathrm{m}^{3}$ & $<20 \mathrm{ppb}$ \\
Alkali & - & $<24 \mathrm{ppb}$ & - & $<10 \mathrm{ppb}$ \\
Chloride & - & $<1 \mathrm{ppm}$ & $<0.1 \mathrm{mg} / \mathrm{m}^{3}$ & $<10 \mathrm{ppb}$ \\
\hline
\end{tabular}

Fluidized bed and entrained flow reactors are the two most likely candidates for carbon negative energy from biomass gasification because of their ability to scale, which will be important for operation at elevated pressure and attainment of comprehensive gas cleaning. It is useful to compare the economic performance in considering their prospects for carbon negative energy. Swanson et al. [66] performed a technoeconomic comparison of low temperature $\left(870{ }^{\circ} \mathrm{C}\right)$ fluidized bed gasification and high temperature $\left(1300{ }^{\circ} \mathrm{C}\right)$ entrained flow gasification at 28 bar, both processing 2000 tons per day to produce FisherTropsch liquids. Despite higher investment costs for the entrained flow gasifier system, its higher product output produced fuel that was $12 \%$ cheaper than from the fluidized bed gasifier. Unfortunately, the capital cost for these plants were estimated to be very high, between $\$ 14.50$ and $\$ 15.40$ per gallon of annual capacity.

Even though fluidized bed gasification produces as much as $10 \mathrm{wt} \%$ char, the primary opportunity for carbon negative energy via biomass gasification is through geological storage of $\mathrm{CO}_{2}$. The amount of $\mathrm{CO}_{2}$ that could be sequestered per metric ton of biomass gasified depends not only on the carbon conversion to gas, but the application of the gas. For example, oxygen-blown entrained flow gasification of wood $\left(\mathrm{CH}_{1.4} \mathrm{O}_{0.66}\right)$ at $20 \%$ equivalence ratio might produce gas containing $93 \%$ of its carbon as $\mathrm{CO}$ and $7 \%$ as $\mathrm{CO}_{2}$ :

$$
\mathrm{CH}_{1.4} \mathrm{O}_{0.66}+0.204 \mathrm{O}_{2} \rightarrow\left(0.932 \mathrm{CO}+0.7 \mathrm{H}_{2}\right)+0.068 \mathrm{CO}_{2}
$$

Sequestering this small fraction of the carbon in the biomass before burning the producer gas for heat or power would be significantly less than the carbon sequestered in biochar from pyrolysis (for fast pyrolysis and slow pyrolysis, respectively, about $20 \%$ and $56 \%$ of the biomass carbon). On the other hand, adding steam to the gasifier or reacting the product gas with steam over a catalyst to water-gas shift the products to a $\mathrm{H}_{2}: \mathrm{CO}$ ratio of 2.0 for gas-to-liquid synthesis would increase the fraction of carbon in $\mathrm{CO}_{2}$ to $53 \%$ :

$$
\left(0.932 \mathrm{CO}+0.7 \mathrm{H}_{2}+0.068 \mathrm{CO}_{2}\right)+0.597 \mathrm{H}_{2} \mathrm{O} \rightarrow\left(0.474 \mathrm{CO}+0.948 \mathrm{H}_{2}\right)+0.526 \mathrm{CO}_{2}
$$


In principle, all the carbon in the product gas could be water-gas shifted to $\mathrm{CO}_{2}$ producing hydrogen gas as the energy product and sequestering $100 \%$ of the carbon as $\mathrm{CO}_{2}$ :

$$
\left(0.932 \mathrm{CO}+0.7 \mathrm{H}_{2}+0.068 \mathrm{CO}_{2}\right)+0.932 \mathrm{H}_{2} \mathrm{O} \rightarrow\left(1.632 \mathrm{H}_{2}\right)+\mathrm{CO}_{2}
$$

The coupling of biomass gasification with $\mathrm{CO}_{2}$ sequestration is known as biomass energy with carbon capture and sequestration (BECCS) [67]. Originally developed to reduce the net $\mathrm{CO}_{2}$ emissions from coal- and gas-fired power plants to near zero, [68] carbon capture and sequestration (CCS) has been expanded into the concept of carbon negative energy via gasification. Even though flue gas from combusting fuels could be scrubbed to remove $\mathrm{CO}_{2}$, typically around 8-14 $\mathrm{vol} \%$, as the calculations in Equations (1)-(3) illustrate, gasification streams that were water-gas shifted for the purpose of fuels production or electric power generation would contain $27-38 \mathrm{vol} \% \mathrm{CO}_{2}$. These high concentrations would significantly reduce the cost of $\mathrm{CO}_{2}$ capture using amines or alkaline aqueous solutions similar to those used by DAC to remove much lower concentrations. Several influential studies suggest that CCS will play an important role in decarbonizing society, [69-71] contributing as much as $80 \%$ of global $\mathrm{CO}_{2}$ emissions reductions by 2050 [71]. Wide-scale deployment of BECCS to provide carbon negative power and fuels is estimated to be able to not simply avoid future GHG emissions but remove 3.5-5.2 Gt/y of $\mathrm{CO}_{2}$ by 2050 [4].

Clearly, gasification has more potential to sequester carbon from a given quantity of biomass than does pyrolysis. However, this important advantage must be balanced against its prominent disadvantages. First is the challenge of reliable and economical long-term storage of gaseous $\mathrm{CO}_{2}$. The density of carbon dioxide stored as supercritical fluid in geological deposits or as dissolved gas in saline aquifers at depths of $800 \mathrm{~m}$ is only $260 \mathrm{~kg} / \mathrm{m}^{3}$ and $35 \mathrm{~kg} / \mathrm{m}^{3}$, respectively [47]. Since carbon only accounts for $27 \%$ of this mass, the actual carbon storage density is $70 \mathrm{~kg} / \mathrm{m}^{3}$ and $9.5 \mathrm{~kg} / \mathrm{m}^{3}$. This compares poorly against biochar with carbon storage density of $364 \mathrm{~kg} / \mathrm{m}^{3}$.

Both sequestration in oceans and geological formations has been proposed. In principle, the high pressures and vast extent of deep ocean waters could sequester more $\mathrm{CO}_{2}$ as dissolved gas or solid $\mathrm{CO}_{2}$ hydrates than would be emitted from combusting the estimated global fossil fuel resources of 5000-10,000 GtC [12]. Small scale, in-situ experiments have established the technical feasibility of ocean storage, [72] but efforts to conduct large scale experiments in the ocean have met with public opposition over concerns about negative impacts on ocean ecosystems [73].

Geological storage includes injecting $\mathrm{CO}_{2}$ as compressed gas or supercritical fluid into porous geological formations that are capped by low permeability caprock (known as hydrodynamic trapping) or into liquids including petroleum reservoirs or saline aquifers (known as solubility trapping) [12]. Hydrodynamic trapping is likely to be the most attractive near-term approach to geological storage while solubility trapping is thought to be more reliable in preventing $\mathrm{CO}_{2}$ gas from returning to the atmosphere. Leakage around injection points or through cracks in the caprock are serious concerns for hydrodynamic cracking. Abrupt leakage through injection well failure or collapse of caprock could cause grievous harm to animals or people [73]. Solubility trapping has the potential advantage of solubilized $\mathrm{CO}_{2}$ reacting with minerals in the geological formation to form carbonates that would permanently sequester carbon, a process known as mineral trapping [74]. Both hydrodynamic and solubility trapping will require site monitoring for very long periods of time.

The energy and cost penalties associated with capturing carbon vs. emitting it into the atmosphere is significant. An analysis in 2015 by Supekar and Skerlos [75] found that adding carbon capture to the flue gas stream from pulverized coal (PC) boilers would decrease power plant thermal efficiency by $11 \%-23 \%$-points increasing electricity costs from $\$ 0.084 / \mathrm{kWh}$ to $\$ 0.14-\$ 0.16 / \mathrm{kWh}$. That same year Sanchez et al. [76] reported that BECCS could produce carbon negative power for $\$ 0.13-\$ 0.19 / \mathrm{kWh}$. BECCS demonstration projects have yet to emerge although a number of integrated coal gasification/electric power generation/carbon sequestration demonstration plants have been planned and/or 
abandoned in the last several years, as detailed in an MIT report by Herzog [77]. As stated by the author, "A major reason [for failure] is the recurring theme of the high cost of gasification. The current technologies just seem too expensive for the power sector". However, the author goes on to note that many of these projects were developed during a period when gas and oil prices dramatically decreased, contributing to the unattractiveness of coal power with or without carbon sequestration.

The Herzog report observes that successful CCS projects have employed already pure streams of $\mathrm{CO}_{2}$ requiring little more than compression, transportation and storage costs. Sanchez et al. [13] reports that $\mathrm{CO}_{2}$ from ethanol plants could be captured and compressed for pipeline transport to sequestration sites for around $\$ 32 / \mathrm{MT}^{\mathrm{C}} \mathrm{O}_{2}$. An IPCC study [73] indicates the cost of transporting $\mathrm{CO}_{2}$ a distance of $250 \mathrm{~km}$ by pipeline and geologically sequestering it would add $\$ 1.60-\$ 16.30 / \mathrm{MT} \mathrm{CO}_{2}$ resulting in the total cost to capture and sequester $\mathrm{CO}_{2}$ from this "biochemical BECCS" system of less than $\$ 50 / \mathrm{MT} \mathrm{CO}$. Not surprising, these appear to be the first BECCS systems to move toward commercialization [78].

Finally, the scale of gasification might not be compatible with biomass resources, especially when integrated with gas turbine power cycles and gas-to-liquids synthesis. These energy products require pressurized gasifiers and extensive gas cleaning operations, which are only economical in large-scale deployments. Experience in the advanced biofuels industry suggest that the low bulk density of biomass and the distributed nature of this resource is incompatible with the $2000 \mathrm{MT} / \mathrm{d}$ scale originally envisioned by the U.S. DOE for advanced biorefineries [79].

\section{Conclusions}

Carbon negative energy is achieved by combining net carbon removal from the atmosphere with the production of energy or other revenue-generating products beyond sequestered carbon. Pyrolysis and gasification of biomass can produce both energy and carbon sequestration agents in the form of biochar and/or $\mathrm{CO}_{2}$. Gasification of biomass to hydrogen for use in transportation and power generation is attractive for the large amounts of carbon that can be sequestered. However, gasification faces several challenges including the difficulty of providing biomass at the scale appropriate to the economical operation of such plants and the difficulties of cheaply and reliably storing $\mathrm{CO}_{2}$ in oceans or geological formations. Pyrolysis is attractive for its relative simplicity and suitability for operation at scales more aligned with the distributed nature of biomass resources. Biochar from pyrolysis is an attractive carbon sequestration product because of its recalcitrance in soils and the ecosystem services it can provide. Slow pyrolysis produces large quantities of biochar, comparable to the amount of carbon that can be sequestered by gasification-based biofuels production. Fast pyrolysis produces less biochar than slow pyrolysis but has superior economics because the bio-oil can be upgraded to energy-rich, carbon-negative liquid fuels or other products. While thermochemical approaches to carbon negative energy will likely be very competitive with DAC, early on it will have difficulty competing with "biochemical BECCS" that sequester the pure streams of $\mathrm{CO}_{2}$ co-product from grain ethanol plants. However, the ability of thermochemical CCS to utilize lignocellulosic biomass, which is less supply constrained than sugar and starch crops used in ethanol production, will make it attractive as demand for carbon negative energy expands.

Funding: This research received no external funding.

Institutional Review Board Statement: Not applicable.

Informed Consent Statement: Not applicable.

Conflicts of Interest: The author declares no conflict of interest. 


\section{References}

1. IPCC. Climate Change 2014: Mitigation of Climate Change. Intergovernmental Panel on Climate Change; IPCC: Cambridge, UK, 2015.

2. Savaresi, A. The Paris Agreement: A New Beginning? J. Energy Nat. Resour. Law 2016, 34, 16-26. [CrossRef]

3. Stout, B.; Lal, R.; Monger, C. Carbon Capture and Sequestration: The Roles of Agriculture and Soils. Int. J. Agric. Biol. Eng. 2016, 9, 1-8.

4. NASEM. Negative Emissions Technologies and Reliable Sequestration; National Academy of Sciences: Washington, DC, USA, 2019. [CrossRef]

5. Lackner, K.S. The Thermodynamics of Direct Air Capture of Carbon Dioxide. Energy 2013, 50, 38-46. [CrossRef]

6. Minx, J.C.; Lamb, W.F.; Callaghan, M.W.; Fuss, S.; Hilaire, J.; Creutzig, F.; Amann, T.; Beringer, T.; De Oliveira Garcia, W.; Hartmann, J.; et al. Negative Emissions-Part 1: Research Landscape and Synthesis. Environ. Res. Lett. 2018, 13, 063001. [CrossRef]

7. Ahmed, N.; Bunting, S.W.; Glaser, M.; Flaherty, M.S.; Diana, J.S. Can Greening of Aquaculture Sequester Blue Carbon? Ambio 2017, 46, 468-477. [CrossRef]

8. Keith, D.W.; Holmes, G.; St. Angelo, D.; Heidel, K. A Process for Capturing $\mathrm{CO}_{2}$ from the Atmosphere. Joule 2018, 2, 1573-1594. [CrossRef]

9. Socolow, R.; Desmond, M.; Aines, R.; Blackstock, J.; Bolland, O.; Kaarsberg, T.; Lewis, N.; Mazzotti, M.; Pfeffer, A.; Sawyer, K.; et al. Direct Air Capture of $\mathrm{CO}_{2}$ with Chemicals; The American Physical Society: Washington, DC, USA, 2011.

10. Sanz-Perez, E.S.; Murdock, C.R.; Didas, S.A.; Jones, C.W. Direct Capture of $\mathrm{CO}_{2}$ from Ambient Air. Chem. Rev. 2016, 116, 11840-11876. [CrossRef]

11. Tollefson, J. Price of Sucking $\mathrm{CO}_{2}$ from Air Plunges. Nature 2018, 558, 173. [CrossRef]

12. Reichle, D.; Houghton, J.; Kane, B.; Ekmann, J.; Benson, S.; Clarke, J.; Dahlman, R.; Hendry, G.; Herzog, H.; Hunter-Cevera, J.; et al. Carbon Sequestration: Research and Development; DOE/SC/FE-1; U.S. Department of Energy: Washington, DC, USA, December 1999.

13. Sanchez, D.L.; Johnson, N.; McCoy, S.T.; Turner, P.A.; Mach, K.J. Near-Term Deployment of Carbon Capture and Sequestration from Biorefineries in the United States. Proc. Natl. Acad. Sci. USA 2018, 115, 4875-4880. [CrossRef]

14. Perlack, R.D. Biomass as Feedstock for a Bioenergy and Bioproducts Industry: The Technical Feasibility of a Billion-Ton Annual Supply; ORNL/TM-2005/66, U.S. Department of Energy: Oak Ridge, TN, USA, April 2005.

15. Perlack, R.D.; Stokes, B.J. U.S. Billion-Ton Update: Biomass Supply for a Bioenergy and Bioproducts Industry; ORNL/TM-2011/224; U.S. Department of Energy: Oak Ridge, TN, USA, August 2011.

16. Langholtz, M.H.; Stokes, B.J.; Eaton, L.M. 2016 Billion-Ton Report: Advancing Domestic Resources for a Thriving Bioeconomy, Volume 1: Economic Availability of Feedstock; ORNL/TM-2016/160; U.S. Department of Energy: Oak Ridge, TN, USA, July 2016.

17. Ghosh, A.; Haverly, M.R. Solvent Liquefaction. In Thermochemical Processing of Biomass; John Wiley \& Sons, Ltd: Chichester, UK, 2019; pp. 257-306. [CrossRef]

18. Brown, R.C.; Brown, T.R. Biorenewable Resources: Engineering New Products from Agriculture, 2nd ed.; John Wiley \& Sons: Chichester, Wessex, UK, 2014. [CrossRef]

19. Broer, K.M.; Peterson, C. Gasification. In Thermochemical Processing of Biomass; Brown, R.C., Ed.; John Wiley \& Sons: Chichester, Wessex, UK, 2019; pp. 85-123.

20. Ahmad, A.A.; Zawawi, N.A.; Kasim, F.H.; Inayat, A.; Khasri, A. Assessing the Gasification Performance of Biomass: A Review on Biomass Gasification Process Conditions, Optimization and Economic Evaluation. Renew. Sustain. Energy Rev. 2016, 53, $1333-1347$. [CrossRef]

21. Brown, R.C. Heterodoxy in Fast Pyrolysis of Biomass. Energy Fuels 2021, 35, 987-1010. [CrossRef]

22. Venderbosch, R.H. Fast Pyrolysis. In Thermochemical Processing of Biomass: Conversion into Fuels, Chemicals and Power; Brown, R.C., Ed.; John Wiley and Sons: Hoboken, NJ, USA, 2019.

23. Yan, Q.; Toghiani, H.; Yu, F.; Cai, Z.; Zhang, J. Effects of Pyrolysis Conditions on Yield of Bio-Chars from Pine Chips. For. Prod. J. 2011, 61, 367-371. [CrossRef]

24. Angin, D. Effect of Pyrolysis Temperature and Heating Rate on Biochar Obtained from Pyrolysis of Safflower Seed Press Cake. Bioresour. Technol. 2013, 128, 593-597. [CrossRef] [PubMed]

25. Antal, M.J.; Allen, S.G.; Dai, X.; Shimizu, B.; Tam, M.S.; Grønli, M. Attainment of the Theoretical Yield of Carbon from Biomass. Ind. Eng. Chem. Res. 2000, 39, 4024-4031. [CrossRef]

26. Bellais, M. Modelling of the Pyrolysis of Large Wood Particles; KTH-Royal Institute of Technology: Stockholm, Sweden, 2007.

27. Manyà, J.J. Pyrolysis for Biochar Purposes: A Review to Establish Current Knowledge Gaps and Research Needs. Environ. Sci. Technol. 2012, 46, 7939-7954. [CrossRef] [PubMed]

28. Antal, M.J.; Croiset, E.; Dai, X.; DeAlmeida, C.; Mok, W.S.L.; Norberg, N.; Richard, J.R.; Al Majthoub, M. High-Yield Biomass Charcoal. Energy Fuels 1996, 10, 652-658. [CrossRef]

29. Mok, W.S.L.; Antal, M.J. Effects of Pressure on Biomass Pyrolysis. II: Heats of Reaction of Cellulose Pyrolysis. Thermochem. Acta 1983, 68, 165-186. [CrossRef]

30. Ronsse, F.; Bai, X.; Prins, W.; Brown, R.C. Secondary Reactions of Levoglucosan and Char in the Fast Pyrolysis of Cellulose. Environ. Prog. Sustain. Energy 2012, 31, 256-260. [CrossRef]

31. Patwardhan, P.R.; Brown, R.C.; Shanks, B.H. Understanding the Fast Pyrolysis of Lignin. ChemSusChem 2011, 4, 1629-1636. [CrossRef] 
32. Bai, X.; Kim, K.H.; Brown, R.C.; Dalluge, E.; Hutchinson, C.; Lee, Y.J.; Dalluge, D. Formation of Phenolic Oligomers during Fast Pyrolysis of Lignin. Fuel 2014, 128, 170-179. [CrossRef]

33. Proano-Aviles, J.; Lindstrom, J.K.; Johnston, P.A.; Brown, R.C. Heat and Mass Transfer Effects in a Furnace-Based Micropyrolyzer. Energy Technol. 2017, 5, 189-195. [CrossRef]

34. Gable, P.; Brown, R.C. Effect of Biomass Heating Time on Bio-Oil Yields in a Free Fall Fast Pyrolysis Reactor. Fuel 2016, 166, 361-366. [CrossRef]

35. Mourant, D.; Lievens, C.; Gunawan, R.; Wang, Y.; Hu, X.; Wu, L.; Syed-Hassan, S.S.A.; Li, C.Z. Effects of Temperature on the Yields and Properties of Bio-Oil from the Fast Pyrolysis of Mallee Bark. Fuel 2013, 108, 400-408. [CrossRef]

36. Boateng, A.A.; Garcia-Perez, M.; Mašek, O.; Brown, R.C.; del Campo, B. Chapter 4: Biochar Production Technology. In Biochar for Environmental Management: Science and Technology; Taylor \& Francis Group: Boca Raton, FL, USA, 2015.

37. Daugaard, D.E.; Brown, R.C. Enthalpy for Pyrolysis for Several Types of Biomass. Energy Fuels 2003, 17, 934-939. [CrossRef]

38. Kunii, D.; Levenspiel, O. Fluidization Engineering, 2nd ed.; Butterworth-Heinemann: Boston, MA, USA, 1991. [CrossRef]

39. Campuzano, F.; Brown, R.C.; Martinez, J.D. Auger Reactors for Pyrolysis of Biomass and Wastes. Renew. Sustain. Energy Rev. 2019, 102, 372-409. [CrossRef]

40. Brown, R.C. Process Intensification through Directly Coupled Autothermal Operation of Chemical Reactors. Joule 2020, 4, 1-22. [CrossRef]

41. Brown, R.C.; del Campo, B.; Boateng, A.A.; Garcia-Perez, M.; Mašek, O. Chapter 3: Fundamentals of Biochar Production. In Biochar for Environmental Management: Science, Technology and Implementation; Lehmann, J., Joseph, S., Eds.; Taylor \& Francis Group: London, UK, 2015; pp. 39-61. [CrossRef]

42. Polin, J.P.; Peterson, C.A.; Whitmer, L.E.; Smith, R.G.; Brown, R.C. Process Intensification of Biomass Fast Pyrolysis through Autothermal Operation of a Fluidized Bed Reactor. Appl. Energy 2019, 249, 276-285. [CrossRef]

43. Polin, J.P.; Carr, H.D.; Whitmer, L.E.; Smith, R.G.; Brown, R.C. Conventional and Autothermal Pyrolysis of Corn Stover: Overcoming the Processing Challenges of High-Ash Agricultural Residues. J. Anal. Appl. Pyrolysis 2019, 143, 104679. [CrossRef]

44. Brown, T.R.; Wright, M.M.; Brown, R.C. Estimating Profitability of Two Biochar Production Scenarios: Slow Pyrolysis vs. Fast Pyrolysis. Biofuels Bioprod. Biorefin. 2011, 5, 54-68. [CrossRef]

45. Marmiroli, M.; Bonas, U.; Imperiale, D.; Lencioni, G.; Mussi, F.; Marmiroli, N.; Maestri, E. Structural and Functional Features of Chars from Different Biomasses as Potential Plant Amendments. Front. Plant Sci. 2018, 9, 1119. [CrossRef]

46. Brewer, C.E.; Chuang, V.J.; Masiello, C.A.; Gonnermann, H.; Gao, X.; Dugan, B.; Driver, L.E.; Panzacchi, P.; Zygourakis, K.; Davies, C.A. New Approaches to Measuring Biochar Density and Porosity. Biomass Bioenergy 2014, 66, 176-185. [CrossRef]

47. Bruant, R.G., Jr.; Guswa, A.J.; Celia, M.A.; Peters, C.A. Safe Storage of $\mathrm{CO}_{2}$ in Deep Saline Aquifers. Environ. Sci. Technol. 2002, 36, 240A-245A. [CrossRef] [PubMed]

48. Lehmann, J.; Czimczik, C.; Laird, D.; Sohi, S. Stability of Biochar in Soil. In Biochar for Environmental Management; Lehmann, J., Stephen, J., Eds.; Earthscan: London, UK, 2009; pp. 183-206.

49. Laird, D.A. The Charcoal Vision: A Win-Win-Win Scenario for Simultaneously Producing Bioenergy, Permanently Sequestering Carbon, While Improving Soil and Water Quality. Agron. J. 2008, 100, 178-181.

50. Gao, S.; DeLuca, T.H.; Cleveland, C.C. Biochar Additions Alter Phosphorus and Nitrogen Availability in Agricultural Ecosystems: A Meta-Analysis. Sci. Total Environ. 2019, 654, 463-472. [CrossRef]

51. Jeffery, S.; Verheijen, F.G.A.; van der Velde, M.; Bastos, A.C. A Quantitative Review of the Effects of Biochar Application to Soils on Crop Productivity Using Meta-Analysis. Agri. Ecosys. Environ. 2011, 144, 175-187. [CrossRef]

52. Lal, R.; Smith, P.; Jungkunst, H.F.; Mitsch, W.J.; Lehmann, J.; Ramachandran Nair, P.K.; McBratney, A.B.; De Moraes Sá, J.C.; Schneider, J.; Zinn, Y.L.; et al. The Carbon Sequestration Potential of Terrestrial Ecosystems. J. Soil Water Conserv. 2018, 73, 145A-152A. [CrossRef]

53. Bakshi, S.; Banik, C.; Laird, D.A. Quantification and Characterization of Chemically-and Thermally-Labile and Recalcitrant Biochar Fractions. Chemosphere 2018, 194, 247-255. [CrossRef]

54. Laird, D.A.; Brown, R.C.; Amonette, J.E.; Lehmann, J. Review of the Pyrolysis Platform for Coproducing Bio-Oil and Biochar. Biofuels Bioprod. Biorefin. 2009, 3, 547-562. [CrossRef]

55. Fast Pyrolysis of Biomass: Advances in Science and Technology; Brown, R.C.; Wang, K. (Eds.) Royal Society of Chemistry: London, UK, 2017.

56. Dieringer, P.; Marx, F.; Alobaid, F.; Ströhle, J.; Epple, B. Process Control Strategies in Chemical Looping Gasification-A Novel Process for the Production of Biofuels Allowing for Net Negative $\mathrm{CO}_{2}$ Emissions. Appl. Sci. 2020, 10, 4271. [CrossRef]

57. Acharya, B.; Roy, P.; Dutta, A. Review of Syngas Fermentation Processes for Bioethanol. Biofuels 2014, 5, 551-564. [CrossRef]

58. Breault, R.W. Gasification Processes Old and New: A Basic Review of the Major Technologies. Energies 2010, 3, 216-240. [CrossRef]

59. The Coal Handbook: Towards Cleaner Production, Vol 2: Coal Utilisation; Osborne, D. (Ed.) Woodhead Publishing: Oxford, UK, 2013.

60. Barakat, A.; Monlau, F.; Solhy, A.; Carrere, H. Mechanical Dissociation and Fragmentation of Lignocellulosic Biomass: Effect of Initial Moisture, Biochemical and Structural Proprieties on Energy Requirement. Appl. Energy 2015, 142, 240-246. [CrossRef]

61. Colin, B.; Dirion, J.L.; Arlabosse, P.; Salvador, S. Quantification of the Torrefaction Effects on the Grindability and the Hygroscopicity of Wood Chips. Fuel 2017, 197, 232-239. [CrossRef]

62. Ma, C. Overview of Ash-Related Matters during Pressurised Entrained-Flow Gasification; Report No. SE-97187; Lulea University of Technology: Lulea, Sweden, 2015. 
63. Alewell, C.; Ringeval, B.; Borrelli, P.; Ballabio, C.; Robinson, D.A.; Panagos, P. Global Phosphorus Shortage Will Be Aggravated by Soil Erosion. Nat. Commun. 2020, 11, 4546. [CrossRef]

64. Woolcock, P.J.; Brown, R.C. A Review of Cleaning Technologies for Biomass-Derived Syngas. Biomass Bioenergy 2013, 52, 54-84. [CrossRef]

65. Abdoulmoumine, N.; Adhikari, S.; Kulkarni, A.; Chattanathan, S. A Review on Biomass Gasification Syngas Cleanup. Appl. Energy 2015, 155, 294-307. [CrossRef]

66. Swanson, R.M.; Platon, A.; Satrio, J.A.; Brown, R.C. Techno-Economic Analysis of Biomass-to-Liquids Production Based on Gasification. Fuel 2010, 89 (Suppl. 1), S11-S19. [CrossRef]

67. Sanchez, D.L.; Kammen, D.M. A Commercialization Strategy for Carbon-Negative Energy. Nat. Energy 2016, 1, 2. [CrossRef]

68. Finkenrath, M. Carbon Dioxide Capture from Power Generation-Status of Cost and Performance. Chem. Eng. Technol. 2012, 35, 482-488. [CrossRef]

69. Pacala, S.; Socolow, R. Stabilization Wedges: Solving the Climate Problem for the next 50 Years with Current Technologies. Plan. Clim. Chang. A Read. Green Infrastruct. Sustain. Des. Resilient Cities 2018, 305, 55-61. [CrossRef]

70. Williams, J.H.; DeBenedictis, A.; Ghanadan, R.; Mahone, A.; Moore, J.; Morrow, W.R.; Price, S.; Torn, M.S. The Technology Path to Deep Greenhouse Gas Emissions Cuts by 2050: The Pivotal Role of Electricity. Science 2012, 335, 53-59. [CrossRef] [PubMed]

71. Hertwich, E.G.; Gibon, T.; Bouman, E.A.; Arvesen, A.; Suh, S.; Heath, G.A.; Bergesen, J.D.; Ramirez, A.; Vega, M.I.; Shi, L. Integrated Life-Cycle Assessment of Electricity-Supply Scenarios Confirms Global Environmental Benefit of Low-Carbon Technologies. Proc. Natl. Acad. Sci. USA 2015, 112, 6277-6282. [CrossRef] [PubMed]

72. Brewer, P.G.; Friederich, G.; Peltzer, E.T.; Orr, F.M., Jr. Direct Experiments on the Ocean Disposal of Fossil Fuel $\mathrm{CO}_{2}$. Science 1999, 284, 943-945. [CrossRef]

73. IPCC. Carbon Dioxide Capture and Storage; Metz, B., Davidson, O., de Coninck, H., Loos, M., Meyer, L., Eds.; Cambridge University Press: Cambridge, CA, USA, 2005.

74. Ajayi, T.; Gomes, J.S.; Bera, A. A Review of $\mathrm{CO}_{2}$ Storage in Geological Formations Emphasizing Modeling, Monitoring and Capacity Estimation Approaches. Pet. Sci. 2019, 16, 1028-1063. [CrossRef]

75. Supekar, S.D.; Skerlos, S.J. Reassessing the Efficiency Penalty from Carbon Capture in Coal-Fired Power Plants. Environ. Sci. Technol. 2015, 49, 12576-12584. [CrossRef] [PubMed]

76. Sanchez, D.L.; Nelson, J.H.; Johnston, J.; Mileva, A.; Kammen, D.M. Biomass Enables the Transition to a Carbon-Negative Power System across Western North America. Nat. Clim. Chang. 2015, 5, 230-234. [CrossRef]

77. Herzog, H. Lessons Learned from CCS Demonstration and Large Pilot Projects; MIT Energy Initiative Working Paper; Massachusetts Institute of Technology: Cambridge, MA, USA, 2016.

78. Voegele, E. Large-Scale CCS Projects Will Sequester $\mathrm{CO}_{2}$ from Ethanol Plants. Ethanol Prod. Mag. 2021. Available online: http: / / www.ethanolproducer.com/articles/18001/large-scale-ccs-project-will-sequester-co2-from-ethanol-plants (accessed on 12 May 2021).

79. Daugaard, T.; Mutti, L.A.; Wright, M.M.; Brown, R.C.; Componation, P. Learning Rates and Their Impacts on the Optimal Capacities and Production Costs of Biorefineries. Biofuels Bioprod. Biorefin. 2014, 9, 82-94. [CrossRef] 